\title{
DACTYLOGYRUS INFESTATION IN FARMED COMMON CARP Cyprinus carpio FROM AQUACULTURE FACILITIES IN MACEDONIA
}

\author{
Dijana Blazhekovikj - Dimovska ${ }^{1 *}$, Stojmir Stojanovski \\ ${ }^{1}$ University "St. Kliment Ohridski", Faculty of Biotechnical Sciences, Partizanska b.b. 7000 Bitola, N. Macedo- \\ nia \\ ${ }^{2}$ Hydrobiological Institute, Naum Ohridski 50, 6000 Ohrid, N. Macedonia
}

*Corresponding Author: dijanablazekovic@yahoo.com

\section{ARTICLE INFO}

Received: 23 November 2020

Accepted: 2 August 2021

\begin{abstract}
A total of 958 specimens of farmed common carp Cyprinus carpio from eight of the most significant and largest cyprinid aquaculture facilities in Macedonia (pond and cage culture systems) were examined for parasitological investigation for three years. The following parasite species of the genus Dactylogyrus were identified: Dactylogyrus extensus, Dactylogyrus minutus and Dactylogyrus anchoratus. The highest prevalence was determined for $D$. extensus (38.8\%), followed by $D$. minutus $(7.9 \%)$ and $D$. anchoratus (2.8\%). The highest mean intensity was determined for $D$. extensus (6.2), followed by D. minutus (4.7) and D. anchoratus (3.8). By seasons, the highest prevalence (16.5\%) was recorded for $D$. extensus in winter, while the lowest $(0.6 \%)$ for $D$. minutus in autumn. The highest mean intensity (8.0) was also determined for $D$. extensus in winter, and the lowest (1.9) for $D$. minutus in spring.
\end{abstract}

Blazhekovikj-Dimovska, D., Stojanovski, S. (2021): Dactylogyrus infestation in farmed common carp Cyprinus carpio from aquaculture facilities in Macedonia. Croatian Journal of Fisheries, 79, 157-162. DOI: 10.2478/cjf2021-0017. 


\section{INTRODUCTION}

The family Dactylogyridae includes many parasite species that mainly parasitize on the gills of freshwater fish. Dove and Ernst (1998) considered that Dactylogyrus sp. is one of the largest genera of parasitic helminths, $95 \%$ of which are parasites on the gills of fish from the family Cyprinidae. The genus Dactylogyrus includes more than 200 parasite species that are characterized by different pathogenicity. The composition and dimensions of certain parts of the hooks are important factors in determining these parasites. The copulatory organ is chitinoid and consists of a tube and an auxiliary apparatus of different shapes, sizes and interactions in different types of dactylogiruses (Bauer, 1985).

According to Woo (2006), members of the genus Dactylogyrus represent the largest group of fish ectoparasites and are of great importance for fish pathology. Young fish are more at risk of infection with these parasites, which can lead to disease and high mortality in hatcheries, but adult fish are not excluded. Kearn (1994) stated that, in general, most species of the genus Dactylogyrus are strictly host-specific, or are limited to one or more closely related hosts.

Shaharom-Harrison (1986) and Cable et al. (1998) stated that the development of dactylogyruses is usually rapid, lasting 4 - 5 days, and their lifespan is short, lasting 5 40 days. These parasites develop various mechanisms to increase the possibility of attaching to the host, such as the opening of the oncomiracids during the period when the fish is resting on the bottom. They also develop mechanisms to resist chemical and physical stressors in the environment.

The main aim of this study was to determine the parasite fauna of the genus Dactylogyrus in common carp Cyprinus carpio L. 1758 from aquaculture facilities in Macedonia, to identify Dactylogyrus species, as well as to determine their changes in intensity and prevalence level depending on the season and sampling sites. In this research, the most important aquaculture facilities in Macedonia were included for the first time.

\section{MATERIALS AND METHODS}

Fish material from 958 specimens of farmed common carp Cyprinus carpio sampled from the most significant and largest cyprinid aquaculture facilities in Macedonia, including fish ponds and cage farms on reservoirs (Fig. 1), was examined for parasitological investigations. This study was carried out by seasons for three years (2018 - 2020). Only fresh fish were subjected to routine identification, dissection and observation. Cleaned parasites were separated, put in appropriate fixatives and prepared for determination using determination techniques of staining and clearing (Vasiljkov, 1983; Gussev, 1983). Parasites on native smears were observed under a light microscope at the magnification of between $\times 100$ and $\times 400$. The parasite specimens were identified using the reference

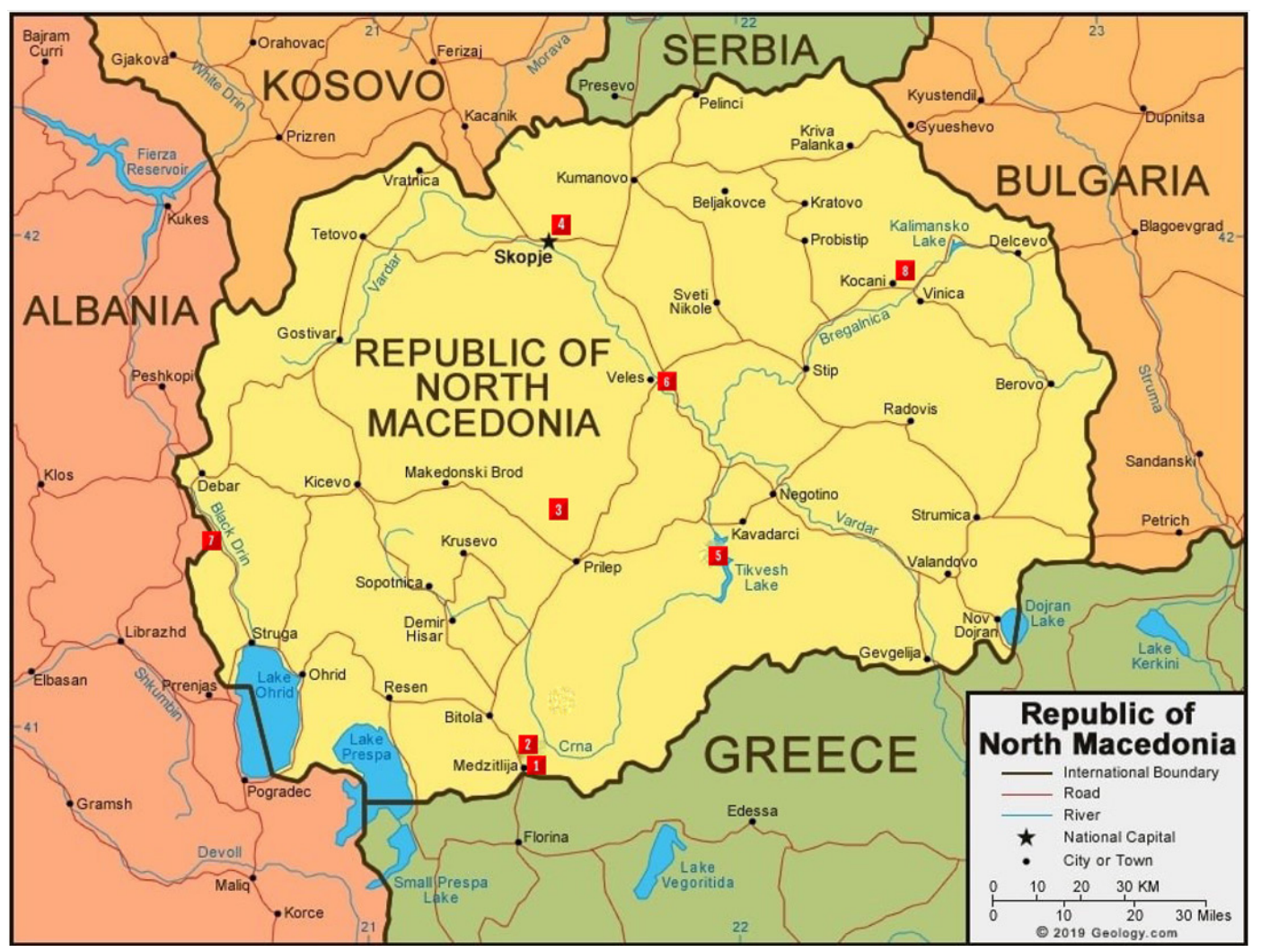

Fig 1. Sampling points - aquaculture facilities (1 - Fish pond Zhabeni; 2 - Fish pond Bukri; 3 - Fish pond Dolneni; 4 - Fish pond Zhelezara; 5 - Tikvesh Reservoir; 6 - Mladost Reservoir; 7 - Globochica Reservoir; 8 - Gradche Reservoir) 
keys of Bauer (1985; 1987) and Gussev (1983). During the examinations at the Department for Fish Diseases in the Institute of Hydrobiology in Ohrid (N. Macedonia), Zeiss stereomicroscopes (Stemi DV4 and MBS 10), as well as light Reichart microscope, were used. Common statistical analyses by calculation of mean prevalence and abundance of parasite species of the genus Dactylogyrus were used.

\section{RESULTS AND DISCUSSION}

During the parasitological examinations of the farmed common carp from the aquaculture facilities in Macedonia, the following species of the genus Dactylogyrus were identified: Dactylogyrus extensus, D. minutus and $D$. anchoratus (Table 1). The most widespread species was $D$. extensus, while $D$. anchoratus was found only at one sampling site.

Based on the total number (958) of examined fish samples of common carp, the highest prevalence of Dactylogyrus species was determined for $D$. extensus (38.8\%), followed by D. minutus (7.9\%) and D. anchoratus (2.8\%). The highest mean intensity with Dactylogyrus species in common carp was determined with $D$. extensus (6.2), followed by D. minutus (4.7) and D. anchoratus (3.8) (Table 2). During this research, it was noticed that the dynamics of parasite occurrence in farmed common carp varies depending on the parasite species and the season. $D$. extensus and $D$. minutus were found in all four seasons, while $D$. anchoratus was found only in the winter.

By seasons, the highest prevalence $(16.5 \%)$ was confirmed for $D$. extensus in the winter, while the lowest $(0.6 \%)$ for $D$. minutus in the autumn (Table 3 ). The highest mean intensity (8.0) was also determined for $D$. extensus in the winter, while the lowest (1.9) for D. minutus in the spring (Table 3).

During our research, $D$. extensus was found at all studied locations except at Globochica Reservoir (Table 1 and $3)$, with different prevalence and mean intensity. Our findings of $D$. extensus in common carp are the first for cyprinid fish ponds Bukri, Dolneni, Zhelezara, as well as for Mladost and Gradche reservoirs. The prevalence of $D$. extensus in farmed common carp by seasons was the highest in the winter and the lowest in the summer, while it was similar in the spring and in the autumn (Table 3 ). Due to specific ecological characteristics, it seems that $D$. extensus grows faster at low temperatures, therefore our results confirmed previous observations. According to Turgut (2012), eggs are resistant to cold water, while larval development is inhibited at $2-3^{\circ} \mathrm{C}$.

$D$. extensus is one of the least host-specific species and it was present in 7 genera of fish (Borji et al., 2012). There is impaired locomotion and poor food intake in fish infected with $D$. extensus and, as a result, they gradually weaken.

Table 1. Recorded Dactylogyrus species by aquaculture facility

\begin{tabular}{lccc}
\hline \hline Aquaculture facility & Dactylogyrus extensus & Dactylogyrus minutus & Dactylogyrus anchoratus \\
\hline Fishpond Zhabeni & $\mathrm{V}$ & $\mathrm{V}$ \\
Fishpond Bukri & $\mathrm{V}$ & $\mathrm{V}$ \\
Fishpond Dolneni & $\mathrm{V}$ & \\
Fishpond Zhelezara & $\mathrm{V}$ & \\
Tikvesh Reservoir & $\mathrm{V}$ & $\mathrm{V}$ \\
Mladost Reservoir & $\mathrm{V}$ & $\mathrm{V}$ \\
Globochica Reservoir & & $\mathrm{V}$ \\
Gradche Reservoir & $\mathrm{V}$ & $\mathrm{V}$ \\
\hline \hline
\end{tabular}

Table 2. Total prevalence (P) and mean intensity (I) with Dactylogyrus spp. in farmed common carp from aquaculture facilities in Macedonia

\begin{tabular}{lccc}
\hline \hline Parasite species & Number of infected fishes & Mean intensity & Prevalence (\%)* \\
\hline Dactylogyrus extensus & 372 & 6.2 & 38.8 \\
Dactylogyrus minutus & 76 & 4.7 & 7.9 \\
Dactylogyrus anchoratus & 27 & 3.8 & 2.8 \\
\hline \hline
\end{tabular}

* The calculations are based on the total number (958) of examined samples of common carp Cyprinus carpio 
Table 3. Prevalence (P) and mean intensity (I) of Dactylogyrus spp. infestation by seasons in farmed common carp from aquaculture facilities in Macedonia

\begin{tabular}{lcccccccc}
\hline \hline \multirow{2}{*}{ Parasite species } & \multicolumn{2}{c}{ Spring } & \multicolumn{2}{c}{ Summer } & \multicolumn{2}{c}{ Autumn } & \multicolumn{2}{c}{ Winter } \\
\cline { 2 - 9 } & I & $\mathbf{P ~ ( \% )}$ & I & $\mathbf{P}(\%)$ & I & $\mathbf{P ~ ( \% )}$ & I & P (\%) \\
\hline Dactylogyrus extensus & 4.0 & 7.0 & 2.5 & 2.8 & 5.5 & 6.3 & 8.0 & 16.5 \\
Dactylogyrus minutus & 1.9 & 0.8 & 4.8 & 4.2 & 3.4 & 0.6 & 6.9 & 1.2 \\
Dactylogyrus anchoratus & $/$ & $/$ & $/$ & $/$ & $/$ & $/$ & 3.8 & 2.4 \\
\hline \hline
\end{tabular}

* The calculations are based on the total number of examined samples (958) of common carp Cyprinus carpio (I- intensity, P- prevalence)

The operculum is dilated and the gills are swollen, pale and covered with a large amount of mucus, bleeding and necrosis. An excessive amount of mucus impairs the function of the respiratory organs and, as a result, suffocation appears. In some cases, gill lesions are an entry point for bacteria and fungi, especially those of the genus Saprolegnia (Daghigh Roohi et al., 2019).

According to our observations, because of the parasitism of $D$. extensus, losses usually occur in young carp farmed in poor conditions, or if young carp in densely populated fish ponds is infested with other parasite species in early spring (Turgut, 2012).

In our research, D. minutus was found on the gills of 76 specimens (7.9\%) of common carp in Bukri and Dolneni fish ponds, as well as Mladost, Globochica and Gradche reservoirs (Fig. 2-7). The mean intensity was a little lower than for $D$. extensus (4.7).

Our findings of $D$. minutus in common carp are the first of all listed cyprinid fish ponds and reservoirs. The prevalence of $D$. minutus by season was the highest in the summer (4.2\%) and lowest in the autumn (0.6\%), while the intensity was the highest in the winter (6.9) and lowest in the spring (1.9) (Table 3). This situation is correlated with the water temperature, which means that the peak of infestation with $D$. minutus corresponds to an increase in water temperature, and the fall of infestation at other seasons coincides with the fall of water temperature.

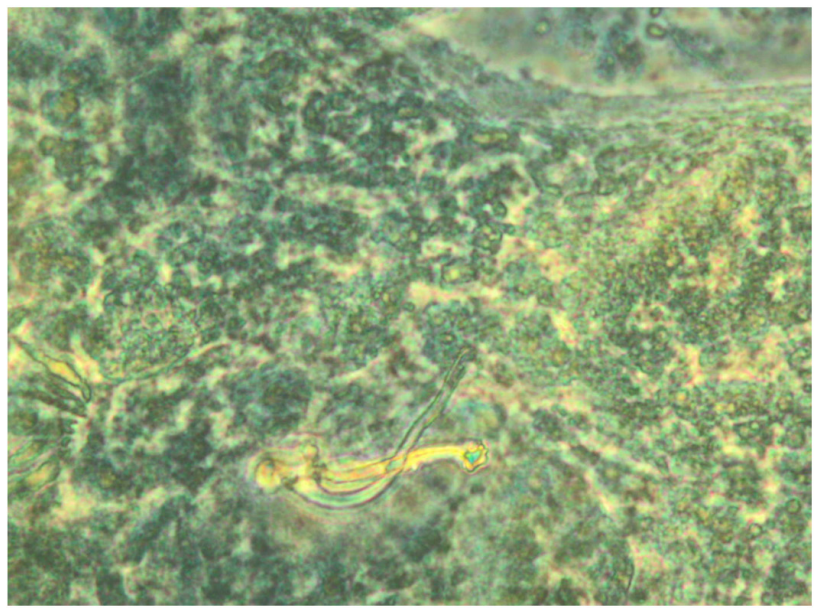

Fig 2. Dactylogyrus extensus on gills of Cyprinus carpio copulatory organ $(\times 400)$

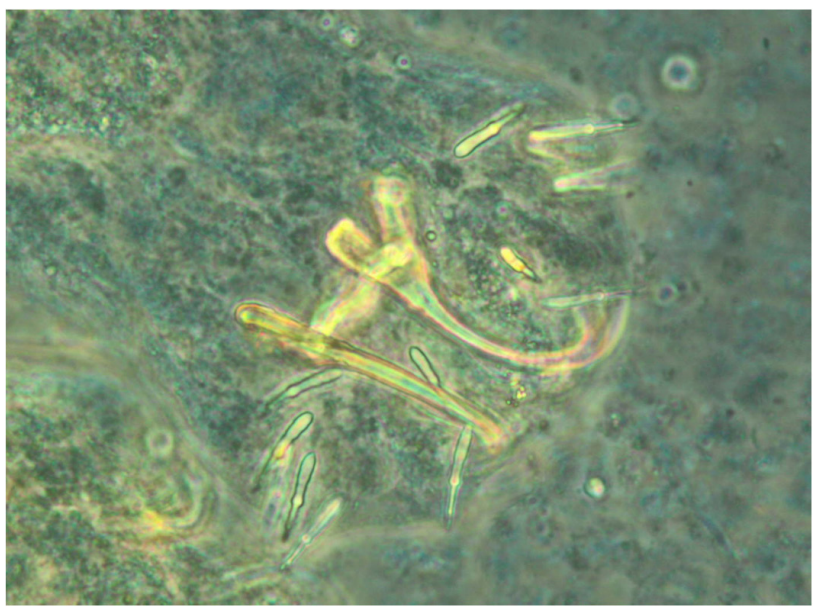

Fig 3. Dactylogyrus extensus on gills of Cyprinus carpio hooks

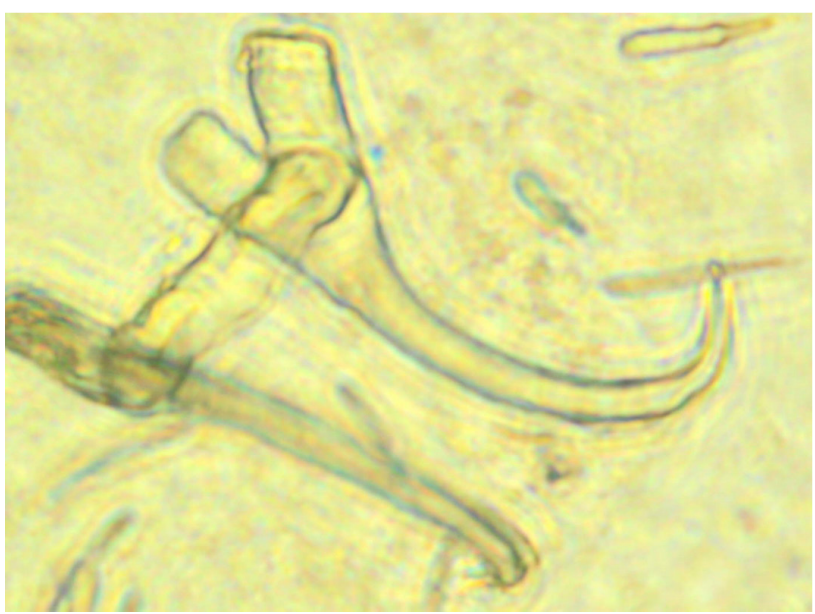

Fig 4. Dactylogyrus extensus on gills of Cyprinus carpio hooks $(\times 400)$

This can be explained by the fact that $D$. minutus is a thermophilic parasite with a shorter life cycle at high temperatures (Silvia, 1991; Pojmanskaya, 1995). This also explains the dominance of this species in the summer months. Aydoğdu and Altunel (2002) also point out that the intensity of infestation with $D$. minutus in common carp changes with water temperature variations. According to the findings of the previous parasitological research in Macedonia, data on the presence of $D$. minutus in wild common carp was published by Hristovski et al. (2003) 


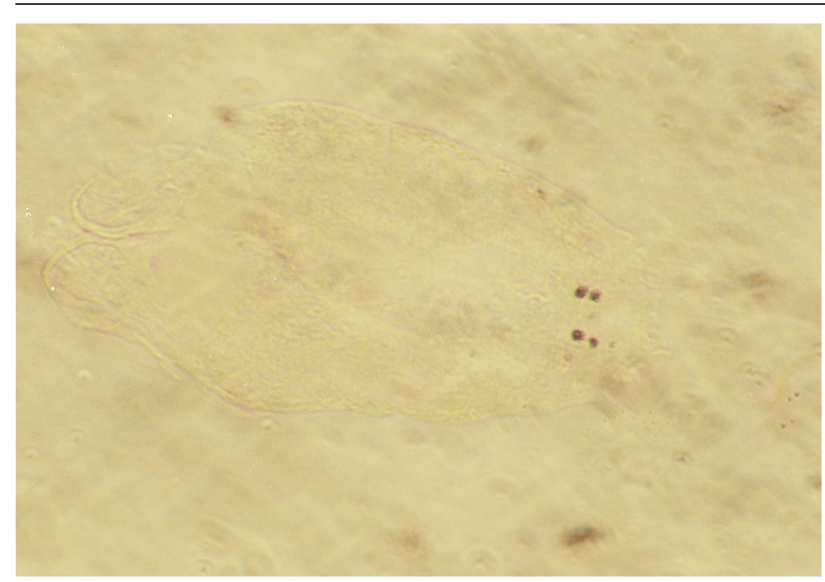

Fig 5. Dactylogyrus minutus on gills of common carp whole parasite

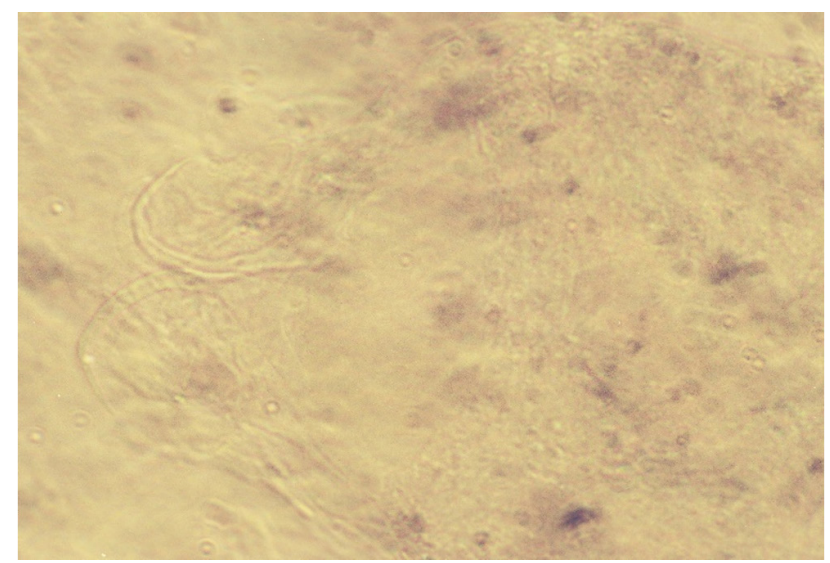

Fig 6. Dactylogyrus minutus on gills of common carp hooks $(\times 200)$

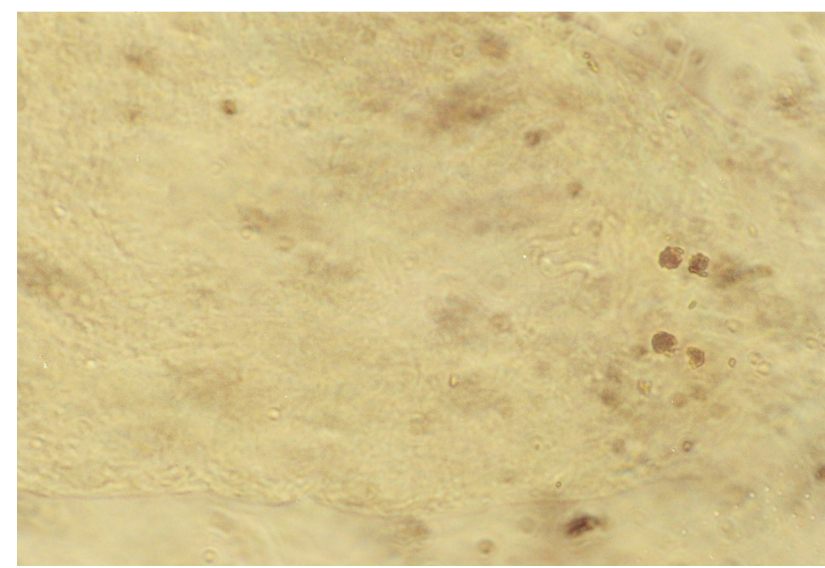

Fig 7. Dactylogyrus minutus on gills of common carp copulatory organ and Stojanovski (2003) in Dojran Lake (with a prevalence of $1.32 \%$ and mean intensity of 1.00 ) and Hristovski et al. $(2006,2012)$ in Prespa Lake with a prevalence of $8.89 \%$. According to the literature reviews in neighbouring countries, the presence of $D$. minutus in common carp in Bosnia and Herzegovina was reported by Žitnan et al. (1969) and Čanković et al. (1976) in the carp fishpond "Vučijak" - Prnjavor, and by Kiškaroly (1987) in the carp fishponds "Bardač", "Prnjavor" and "Saničani" in Prijedor. In Bulgarian waters, a presence of $D$. minutus was reported by Kakacheva-Avramova (1983) and Margaritov (1961, 1962).

In our research, D. anchoratus was found only in Globochica Reservoir in winter, and this is the first finding of $D$. anchoratus in farmed common carp for Macedonia. Accordingly, the prevalence and mean intensity were the lowest for this species (Table 2). Gibson et al. (1996) stated that $D$. anchoratus is one of the least specific species to a host and it has been present in 19 genera of fish, making this species one of the exceptional representatives of the genus Dactylogyrus, due to its wide range of hosts. According to Kakacheva - Avramova (1983), the pathogenic effect of this parasite is not pronounced. It is conditioned only by mechanical damage to the gills. According to the data from previous parasitological researches in Macedonia, $D$. anchoratus was determined by Stojanovski (2003) in wild common carp in Prespa Lake, with a prevalence of $0.93 \%$ and mean intensity of 11.0 . According to the literature reviews from the neighbouring countries, the presence of $D$. anchoratus in common carp in Bosnia and Herzegovina was reported by Žitnan et al. (1969) and Čanković et al. (1976) in the carp fishpond "Vučijak" in Prnjavor, by Teserčik and Ivasik (1973) in the carp fishpond "Majdan", and by Kiškaroly (1987) in the carp fishponds "Bardač", "Prnjavor" and "Saničani" in Prijedor. Ergens (1970) found this parasite in common carp from Skadar and Great Black Lakes, Kakacheva-Avramova (1983) and Margaritov $(1961,1962)$ in Bulgarian waters, while Dupont and Lambert (1986) found it in Lake Micro Prespa in Greece.

Seasonal variations of dactylogiruses are strongly influenced by temperature, the oxygen concentration in the water, and the size and age of the host fish. These findings indicate that the narrow range of tolerance of these species to environmental conditions takes precedence over host specificity.

\section{ZARAZA PARAZITOM DACTYLOGYRUS KOD ŠARANA Cyprinus carpio U AKVAKULTURNIM OBJEKTIMA U MAKEDONIJI}

\section{SAŽETAK}

Za parazitološko istraživanje u trajanju od tri godine pregledano je ukupno 958 primjeraka uzgojenog šarana (Cyprinus carpio) iz osam najznačajnijih i 
najvećih akvakulturnih objekata ciprinida u Makedoniji. Identificirane su sljedeće vrste parazita iz roda Dactylogyrus: Dactylogyrus extensus, Dactylogyrus minutus i Dactylogyrus anchoratus. Najveća prevalencija utvrđena je za $D$. extensus $(38,8 \%)$, zatim za $D$. minutus $(7,9 \%)$ i $D$. anchoratus $(2,8 \%)$. Najveći srednji intenzitet utvrđen je za $D$. extensus $(6,2)$, zatim $D$. minutus $(4,7)$ i $D$. anchoratus $(3,8)$. Prema godišnjim dobima, najveća prevalencija $(16,5 \%)$ zabilježena je za $D$. extensus zimi, dok je najniža $(0,6 \%)$ za $D$. minutus u jesen. Najveći srednji intenzitet $(8,0)$ također je utvrđen za $D$. extensus zimi, a najmanji $(1,9)$ za $D$. minutus u proljeće.

Ključne riječi: Dactylogyrus sp., nametnik, akvakultura, srednji intenzitet, prevalencija

\section{REFERENCES}

Aydoğdu, A., Altunel, F. N. (2002): Helminth parasites (Platyhelminthes) of common carp (Cyprinus carpio L.) in İznik Lake. Bulletin of the European Association of Fish Pathologists, 22 (5), 343-348.

Bauer, O. N. (1985): Opredelitelj parazitov presnovodnih ryb fauni SSSR. Tom II (Parazitiţeskie mnogokletoţnie. Pervaja ţast). Akademia Nauk SSSR. Izdateljstvo "Nauka", Leningrad.

Bauer, O. N. (1987): Opredelitelj parazitov presnovodnih ryb fauni SSSR. Tom III (Parazitiţeskie mnogokletoţnie. Vtoraja ţast). Akademia Nauk SSSR. Izdateljstvo "Nauka", Leningrad.

Borji, H, Naghibi, A., Reza Nasiri, M., Ahmadi, A. (2012): Identification of Dactylogyrus spp. and other parasites of common carp in northeast of Iran. Journal of Parasitic Diseases, 36 (2), 234-238.

Cable, J., Harris, P. D., Tinsley, R. C. (1998): Life history specializations of monogenean flatworms: a review of experimental and microscopical studies. Microscopy Research and Technique, 42 (3), 186-199.

Čanković, M., Žitnan, R., Gradanid, S. (1976): Paraziti iz klase Monogenoidea i njihova epizootiološka važnost kod šarana na jednom ribnjaţarstvu u Bosni i Hercegovini. Veterinaria Sarajevo, 25, 1-2.

Daghigh Roohi, J., Dalimi Asl, A., Pourkazemi, M., Shamsi, S. (2019): Occurrence of dactylogyrid and gyrodactylid Monogenea on common carp, Cyprinus carpio, in the Southern Caspian Sea Basin. Parasitology International, 73, 1-6.

Dove, D. M. A., Ernst, I. (1998): Concurrent invades-four exotic species of monogenea now established on exotic freshwater fishes in Australia. International Journal of Parasitology, 28, 1755-1764.

Dupont, F., Lambert, A. (1986): Etude des communautes de Monogenes Dactylogyridae parasites des Cyprinidae du Lac Mikri Prespa (Nord de la Grece). Description de trois nouvelles especes chez un Barbus endemique: Barbus cyclolepis prespensis Karaman, 1924, Annales de Parasitologie Humaine et Comparee, 61 (6), 597 - 616.

Ergens, R. (1970): Parazitofauna ryb iz teritorii Ternogodii 1. Polinochoinea (Monogenoidea) nekoliko ryb Skadarskog ozera i Boljšego Ternogo ozera. Poljoprivreda i šumarstvo, Titograd XV (1-2), 149-192.

Gibson, D. I., Timofeeva, T. A., Gerasev, P. I. A. (1996): Catalogue of the nominal species of the monogenean genus Dactylogyrus
Diesing, 1850 and their host genera. Systematic Parasitology, 35, 3-48.

Gussev, A. V. (1983): The methods of collection and processing of fish parasitic monogenean materials (In Russian). Nauka. Leningrad. USSR. pp. 25 - 45.

Hristovski, N., Stojanovski, S., Baker, R. A., Petrovic, Z., Rusinek, O., Čakić, P. (2006): Parasite fauna of the fishes from Lake Prespa and life cycle of economically important and most frequently found parasite species, Monography. Faculty of biotechnical sciences. Bitola.

Hristovski, N., Stojanovski, S., Čakić, P., Hristovski, M., Kulisić, Z., Geru, N. (2003): Fauna of monogenean trematods - parasites of carp (Cyprinus carpio) from the Lake Dojran. II Macedonian Symposium of livestock production with international participation. pp. 27-28.

Hristovski, N., Stojanovski, S., Talevski, T., Blažeković - Dimovska, D. (2012): The fish parasite fauna and the fish of Lake Prespa. Monography. National and University library. University "St. Kliment Ohridski". Bitola. Macedonia.

Kakačeva-Avramova, D. (1983): Helminti na slatkovodnite ribi v Bulgaria. Izdatelstvo na Bulgarskata Akademia na Naukite, Sofia.

Kearn, G. C. (1994): Evolutionary expansion of the monogenea. International Journal of Parasitology, 24 (8), 1227-1271.

Kiškaroly, M. (1987): Istraţivanje parazitofaune riba slatkovodnih ribnjaka Bosne i Hercegovine I. Ciprinidni ribnjaci A. Monogeni trematodi 5. Veterinaria, 36 (3-4), 391-397.

Margaritov, N. (1961 - 1962): Ihtioparazitofauna na jazovir Batak. Godišnik na Sofiskija Univerzitet, 1, 105 - 123.

Pojmanskaya, T. (1995): Seasonal dynamics of occurrence and some parasites in four Cyprinid fish cultured in ponds, II. Monogenea. Acta Parasitologica, 40 (2), 79-84.

Shaharom-Harrison, F. (1986): The Reproductive Biology of Dactylogyrus nobilis (Monogenea: Dactylogyridae) from the Gills of Big Head Carp (Aristichthys nobilis). In: Maclean, J. L., Dizon, L. B. and Hosillos, L. V. (eds). The First Asian Fisheries Forum, Asian Fisheries Society, Manila, Philippines, 265-268.

Silvia, L. G., Sepulveda, R., Mercado - Hernandez, R., Martinez, J. J., Salinas, F. (1991): New localities for monogenetic trematodes and other ectoparasites of carp (Cyprinus carpio) and catfish (Ictalunus puncatus) in northeastern Mexico and their relation with some biotic and abiotic factors. The Journal of the Elisa Mitchall Scientific, 106 (3), 64-77.

Stojanovski, S. (2003): Fauna na monogeni trematodi-paraziti kaj ribite od prirodnite ezera vo Makedonija. Doktorska disertacija. Skopje: Fakultet za veterinarna medicina. 157 p.

Teserčik, J, Ivasik, V. (1973): O međusobnim odnosima parazita na škržnom aparatu kod ribljeg mlađa" Ribarstvo Jug. 28 (6), 134-136.

Turgut E. (2012): Influence of temperature and Parasite Intensity of Egg Production and Hatching of the Monogenean Dactylogyrus extensus. The Israeli Journal of Aquaculture Bamidgeh, IJA_64.2012.729, 1-5.

Vasiljkov, G. V. (1983): Gelmintozi ryb. Izdateljstvo "Kolos", Moskva, 45-50.

Woo, P. T. (2006): Fish diseases and disorders. Vol. 1: Protozoan and metazoan infections. CAB International, London, 791p.

Žitnan, R., Kiškaroly, M., Čanković, M. (1969): Epizootiološki odnosi parazitoza ekonomski znaţajnih i bijelih riba u jednom šaranskom gazdinstvu u $\mathrm{BiH}$. Ichthyologia, 1 (1), 99-108. 